\title{
Vitafórum
}

\section{NEM A MENNYISÉG, HANEM A MINŐSÉG SZÁMÍT}

\section{IT'S NOT QUANTITY BUT QUALITY IS WHAT MATTERS}

\author{
Náray-Szabó Gábor \\ az MTA rendes tagja \\ narayszabo@yahoo.com
}

ÖSSZEFOGLALÓ

Nem csökkent, hanem nőtt az akadémiai kutatóintézet-hálózat tudományos teljesítménye az átszervezés óta. Ezt igazolja a közölt publikációk növekvő kumulált idézettsége.

\section{ABSTRACT}

Performance of the institutes of the Hungarian Academy of Sciences did not decrease, but rather have increased since the reorganisation. It has been proven by the increasing cumulative number of citations to their publications.

Kulcsszavak: MTA kutatóintézet-hálózat teljesítménye, átszervezés, idézettség, minőség

Keyword: HAS institutes' output, reorganisation, citations, quality

A Magyar Tudomány 2017/9. számában Vincze Imre azt állítja, hogy jelentős csökkenés tapasztalható az akadémiai kutatóintézet-hálózat tudományos teljesítményében (Vincze, 2017). Ö a teljesítményt a tudományos publikációk számával méri, ennek csökkenése tehát a teljesítmény csökkenését jelenti. Én viszont úgy gondolom, hogy nem a mennyiség, hanem a minőség számít, amit manapság széles körü konszenzus alapján a közleményekre kapott idézetekkel lehet jellemezni. Az MTA intézeteinek éves beszámolójában (URL1, „A kutatóhely főbb mutatói, Hatástényezős és idézettségi mutatók") szereplő számokat felhasználva látható, hogy a három tudományterületen müködő MTA-intézetek kutatói által közölt cikkekre kapott idézetek száma az átszervezés kezdete, 2012 óta folyamatosan nő (lásd 1-3. ábra). 


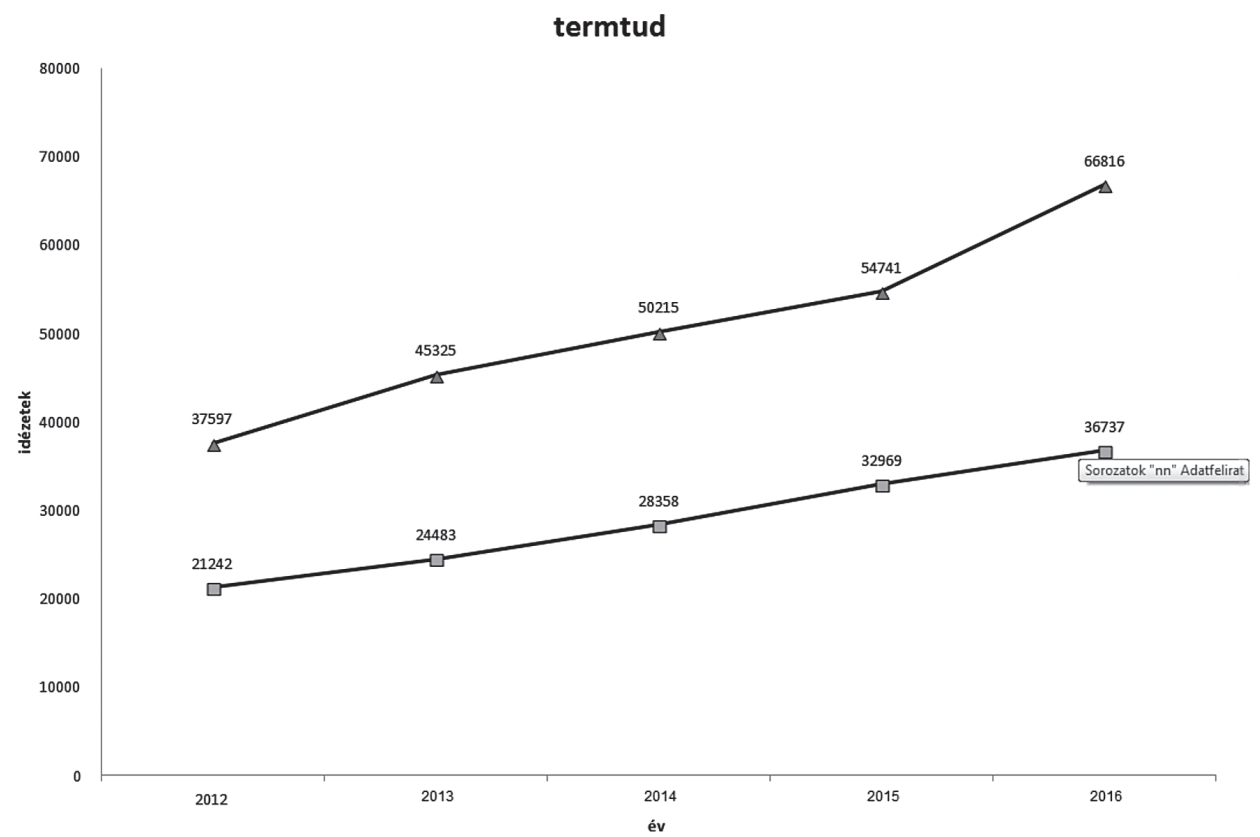

1. ábra. A matematika és természettudományok területén múködő hét intézet tudományos publikációira kapott összes idézetek száma (fent), az ATOMKI és a Wigner Intézet nélkül (lent)

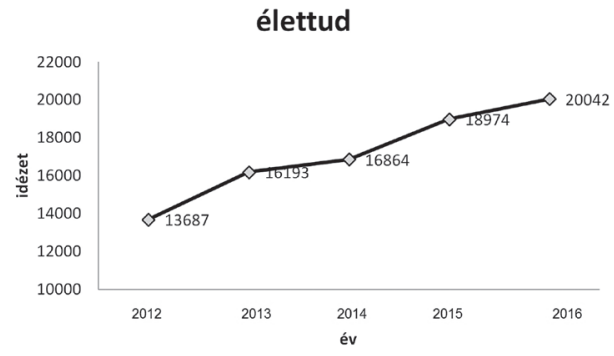

2. ábra. Az élettudományok területén müködő négy intézet tudományos publikációira kapott összes idézetek száma

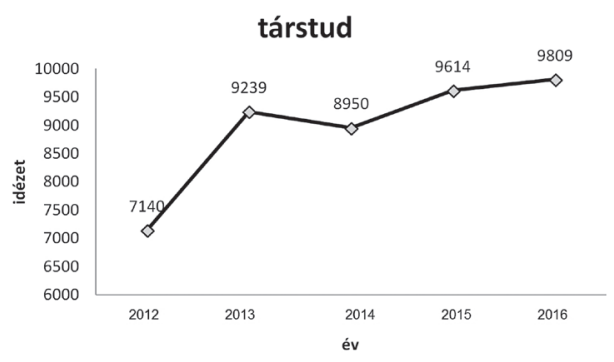

3. ábra. A társadalomtudományok területén működő négy intézet tudományos publikációira kapott összes idézetek száma

A növekedés a természettudományok esetében akkor is megállapítható, ha kihagyjuk a CERN-nel együttmüködő két intézet teljesítményét, mely külön elbírálást igényel.

A mennyiségi csökkenés jelentős minőségi javulással járt, a kutatók színvonalasabb cikkeket írtak, ezt jelzi a növekvő idézetszám. 


\section{IRODALOM}

Vincze I. (2017): Jelentős csökkenés az akadémiai kutatóintézet-hálózat tudományos teljesítményében. Magyar Tudomány, 178, 9, 1114-1117. http://www.matud.iif.hu/2017/09/13.htm

URL1: http://mta.hu/hatteranyagok/az-mta-kutatohelyeinek-eredmenyei-105499 